\begin{tabular}{|c|c|c|}
\hline \multirow{3}{*}{$\begin{array}{r}\text { Case Reports in } \\
\text { Gastroenterology }\end{array}$} & \multirow{2}{*}{\multicolumn{2}{|c|}{ Case Rep Gastroenterol 2016;10:538-544 }} \\
\hline & & \\
\hline & $\begin{array}{l}\text { DOI: 10.1159/000450542 } \\
\text { Publisnea onime: Uctover 10, } 2016\end{array}$ & $\begin{array}{l}\text { (c) } 2016 \text { The Author(s) } \\
\text { Published by S. Karger AG, Basel } \\
\text { www.karger.com/crg }\end{array}$ \\
\hline & $\begin{array}{l}\text { This article is licensed under the } \\
\text { International License (CC BY-NC) } \\
\text { Usage and distribution for commerci }\end{array}$ & $\begin{array}{l}\text { nons Attribution-NonCommercial } 4.0 \\
\text { ger.com/Services/OpenAccessLicense). } \\
\text { juires written permission. }\end{array}$ \\
\hline
\end{tabular}

\title{
Two Patients with Large Colonic Lipomas for which Endoscopic Unroofing was Ineffective
}

\author{
Yuichi Tomiki Koichiro Niwa Kiichi Nagayasu Yu Okazawa \\ Shingo Ito Ryosuke Ichikawa Hisashi Ro Shun Ishiyama \\ Kiichi Sugimoto Kazuhiro Sakamoto \\ Department of Coloproctological Surgery, Faculty of Medicine, Juntendo University, \\ Tokyo, Japan
}

\section{Keywords \\ Colonic lipoma - Endoscopic unroofing - Endoscopic submucosal dissection · Endoscopic treatment}

\begin{abstract}
Endoscopic unroofing is effective for treating large colonic lipomas. However, additional endoscopic resection is occasionally required when the outcomes of initial unroofing are incomplete. The colonoscopy of an 82-year-old woman with abdominal pain revealed a yellowish lipoma of about $20 \mathrm{~mm}$ in the transverse colon. The mass was treated by unroofing, but a follow-up colonoscopy 5 days later revealed residual lipoma. One month later, the regenerated surface had become covered with mucosa, and the status of the lipoma had returned to that before unroofing. The colonoscopy of a 74-year-old man with abdominal pain and melena revealed a $50-\mathrm{mm}$-wide protruding lipoma in the transverse colon. The mucosa of the upper third of the lipoma was excised using an electric knife and snare, which allowed the immediate partial drainage of adipose tissue. Unroofing proceeded, but 7 days later, the unroofed surface had become coated with a white substance, and the residual lipoma required additional endoscopic resection. Colonic lipomas are often asymptomatic. However, patients with abdominal pain and hemorrhage should be treated in consideration of complete resection, but not by unroofing, which could leave a residual tumor. Drainage should be confirmed after unroofing and any residual lipoma should be treated by additional resection.

(c) 2016 The Author(s)

Published by S. Karger AG, Basel
\end{abstract}


Tomiki et al.: Two Patients with Large Colonic Lipomas for which Endoscopic Unroofing was Ineffective

\section{Introduction}

Colonic lipomas are benign mesenchymal tumors that might not require treatment if asymptomatic, whereas large colonic lipomas that cause abdominal pain, hemorrhage, constipation and intussusception require surgical resection. Therefore, it is desirable to treat large colonic lipomas with endoscopic resection [1]. Endoscopic submucosal dissection (ESD) is considered to be effective for treating large lipomas [2]; however, ESD is also associated with the risk of perforation and bleeding [3].

Endoscopic unroofing is a simple, safe and effective procedure that comprises the excision of the upper third of a large lipoma to allow remaining adipose tissue to gradually extrude from the resected stump [1,4-6]. Nonetheless, the outcomes of this procedure are not always positive, and we describe the failure of unroofing to treat two large colonic lipomas.

\section{Case Reports}

Case 1

The colonoscopy of an 82-year-old woman with abdominal pain revealed a 40-mm pedunculated lipoma in the ascending colon and a $20-\mathrm{mm}$ sessile lipoma in the transverse colon (fig. 1a). The pedunculated mass in the ascending colon was resected en bloc by ESD using an electric knife (Dual Knife, Olympus, Tokyo, Japan), and the sessile mass in the transverse colon was treated by unroofing. The upper third of the tumor was resected using an electrocautery snare (Olympus, Tokyo, Japan) (fig. 1b). Follow-up colonoscopy 5 days later revealed an open surface on the unroofed stump and residual lipoma (fig. 1c) that persisted for up to 1 month. By that time, the regenerated surface had become covered with a mucosa, and the lipoma looked the same as it had been before unroofing (fig. 1d). The residual lipoma was not resected because the patient no longer had abdominal pain and requested only follow-up observation.

\section{Case 2}

A 74-year-old man who presented with abdominal pain and melena was diagnosed with a lipoma in the transverse colon and referred to our Department. The colonoscopy revealed a 50-mm-wide lipoma accompanied by mucosal hypertrophy and erosion in the transverse colon (fig. 2a). The mucosa of the upper third of the tumor was circumferentially incised using an electric knife (Dual Knife, Olympus) and resected using an electrocautery snare (Olympus) (fig. 2b, c). Adipose tissue in the lipoma partially drained immediately thereafter (fig. 2d). Seven days later, the unroofed surface had become coated with a white substance (fig. 3a). Since residual adipose tissue was not likely to drain, the lesion was resected piecemeal using an electrocautery snare (fig. 3b, c). One month thereafter, the patient was free of abdominal pain and melena, and the colonoscopy showed that the resected region had become a scar without residual lipoma (fig. $3 \mathrm{~d}$ ).

\section{Discussion}

Endoscopic unroofing is simple and safe, and a useful method of treatment that also enables pathological examinations [1]. The procedure is applicable to a diagnosis not only of 
Tomiki et al.: Two Patients with Large Colonic Lipomas for which Endoscopic Unroofing was Ineffective

lipomas, but also of submucosal masses such as gastrointestinal stromal tumors, leiomyomas, and neuroendocrine carcinomas [7, 8].

We treated colonic lipomas in 2 patients using unroofing, but the outcomes were insufficient in both. We therefore investigated why the remaining lipoma failed to drain. In the 1st patient, the unroofed area of the transverse colon lipoma was small, and only the surface was resected, which might have prevented the drainage of adipose tissue despite it being exposed. Adipose tissue partially drained immediately after unroofing in the 2nd patient, but a hard, thickened mucosa was encapsulated by a submucosal layer that might have prevented the spontaneous drainage of residual fat. Adipose tissue can take several days to weeks to drain from lipomas, but this did not occur within a period of about 1 week in either patient. The mucosa regenerated on the unroofed surface after 1 month in the 1st patient, whereas endoscopic findings showed that adipose tissue had not drained in the 2nd patient within 1 month, and additional endoscopic mucosal resection (EMR) was required. Unroofing resulting in incomplete resection that requires additional EMR has been reported [9]. More investigation is needed about lipomas treated by endoscopic unroofing, particularly those from which adipose tissue does not drain.

Large colonic lipomas can spontaneously detach [10], but treating those $\geq 2 \mathrm{~cm}$ using endoscopic procedures is associated with increased risk of complications such as perforation and hemorrhage [11]. Therefore, in addition to standard EMR, attempts have been made to reduce complications by applying a detachable nylon endoloop or a long clip to the base of large colonic lipomas $[12,13]$. In addition, recent improvements in ESD have allowed the safe resection of large lesions, and large colonic lipomas are now included among the indications for this procedure [14]. However, the risk of complications remains high for endoscopic procedures, and surgical resection is recommended for lipomas with a base that is $\geq 4 \mathrm{~cm}$ or patients with an unclear diagnosis, intussusception-induced obstruction, expansion into the muscle layer and serosa, and incomplete endoscopic resection [15].

Colonic lipomas are often asymptomatic. However, patients with abdominal pain and hemorrhage should be treated in consideration of complete resection, but not by unroofing, which could leave a residual tumor. Drainage should be confirmed after unroofing and any residual lipoma should be treated by additional resection.

\section{Statement of Ethics}

The authors have no ethical conflicts to disclose.

\section{Disclosure Statement}

The authors have no conflicts of interest to declare.

\section{References}

1 Kopáčová M, Rejchrt S, Bureš J: Unroofing technique as an option for the endoscopic treatment of giant gastrointestinal lipomas. Acta Med (Hradec Kralove) 2015;58:115-118.

2 Okada K, Shatari T, Suzuki K, Tamada T, Sasaki T, Suwa T, Hori M, Sakuma M: Is endoscopic submucosal dissection really contraindicated for a large submucosal lipoma of the colon? Endoscopy 2008;40(suppl 2):E227. 
Tomiki et al.: Two Patients with Large Colonic Lipomas for which Endoscopic Unroofing was Ineffective

-3 Matsushita M, Danbara N, Kawamata S, Omiya M, Okazaki K: Endoscopic removal of large colonic lipomas: difficult submucosal dissection or easy snare unroofing? Endoscopy 2009;41:475.

4 Sugimoto K, Sato K, Maekawa H, Sakurada M, Orita H, Ito T, Saita M, Ikota M, Yoshida Y, Yamano M: Unroofing technique for endoscopic resection of a large colonic lipoma. Case Rep Gastroenterol 2012;6:557-562.

5 Soares JB, Gonçalves R, Rolanda C: Endoscopic resection of a large colonic lipoma by unroofing technique. Endoscopy 2011;43(suppl 2):E407.

6 Kim GW, Kwon CI, Song SH, Jin SM, Kim KH, Moon JH, Hong SP, Park PW: Endoscopic resection of giant colonic lipoma: case series with partial resection. Clin Endosc 2013;46:586-590.

7 Binmoeller KF, Shah JN, Bhat YM, Kane SD: Suck-ligate-unroof-biopsy by using a detachable 20-mm loop for the diagnosis and therapy of small subepithelial tumors (with video). Gastrointest Endosc 2014;79:750-755.

-8 Lee CK, Chung IK, Lee SH, Lee SH, Lee TH, Park SH, Kim HS, Kim SJ, Cho HD: Endoscopic partial resection with the unroofing technique for reliable tissue diagnosis of upper GI subepithelial tumors originating from the muscularis propria on EUS (with video). Gastrointest Endosc 2010;71:188-194. Lee KJ, Kim GH, Park do Y, Shin NR, Lee BE, Ryu DY, Kim DU, Song GA: Endoscopic resection of gastrointestinal lipomas: a single-center experience. Surg Endosc 2014;28:185-192. Ishiyama S, Tashiro Y, Nagayasu K, Niwa K, Ono S, Sugimoto K, Hata M, Kamiyama H, Komiyama H, Takahashi M, Yaginuma Y, Kojima Y, Goto M, Tanaka M, Sengoku H, Okuzawa A, Tomiki Y, Sakamoto K: Spontaneous disappearance of a giant colonic lipoma after endoscopic biopsy. Endoscopy 2011;43(suppl 2):E16.

11 Crocetti D, Sapienza P, Sterpetti AV, Paliotta A, DE Gori A, Pedullà G, de Toma G: Surgery for symptomatic colon lipoma: a systematic review of the literature. Anticancer Res 2014;34:6271-6276. Geraci G, Pisello F, Arnone E, Sciuto A, Modica G, Sciumè C: Endoscopic resection of a large colonic lipoma: case report and review of literature. Case Rep Gastroenterol 2010;4:6-11.

-13 Murray MA, Kwan V, Williams SJ, Bourke MJ: Detachable nylon loop assisted removal of large clinically significant colonic lipomas. Gastrointest Endosc 2005;61:756-759.

14 Lee JM, Kim JH, Kim M, Kim JH, Lee YB, Lee JH, Lim CW: Endoscopic submucosal dissection of a large colonic lipoma: report of two cases. World J Gastroenterol 2015;21:3127-3131.

15 Jiang L, Jiang LS, Li FY, Ye H, Li N, Cheng NS, Zhou Y: Giant submucosal lipoma located in the descending colon: a case report and review of the literature. World J Gastroenterol 2007;13:5664-5667. 


\section{Case Reports in Gastroenterology}

\begin{tabular}{l|l}
\hline Case Rep Gastroenterol 2016;10:538-544 \\
\hline DOI: 10.1159/000450542 & $\begin{array}{l}\text { @ 2016 The Author(s). Published by S. Karger AG, Basel } \\
\text { www.karger.com/crg }\end{array}$ \\
\hline
\end{tabular}

Tomiki et al.: Two Patients with Large Colonic Lipomas for which Endoscopic Unroofing was Ineffective
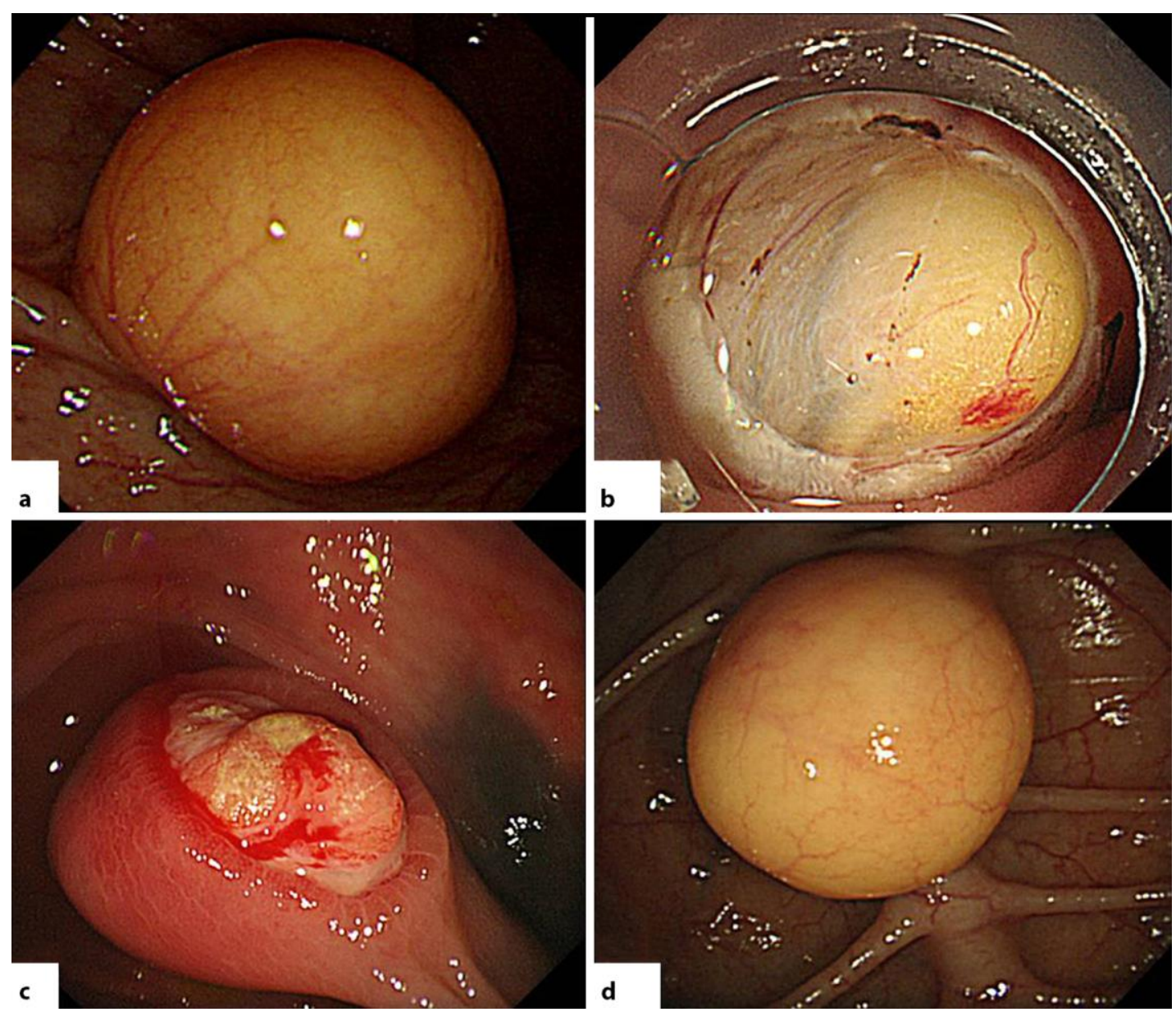

Fig. 1. Colonoscopy findings of lipoma in an 82-year-old woman. a A smooth, yellowish submucosal tumor of about $20 \mathrm{~mm}$ in the transverse colon. $\mathbf{b}$ The upper third of lipoma body was excised using a snare. c The unroofed surface was open, but the lipoma persisted for 5 days. $\mathbf{d}$ The lipoma was covered with regenerated mucosa at 1 month after unroofing. 


\section{Case Reports in Gastroenterology}

\begin{tabular}{l|l}
\hline Case Rep Gastroenterol 2016;10:538-544 \\
\hline DOI: 10.1159/000450542 & $\begin{array}{l}\text { @ 2016 The Author(s). Published by S. Karger AG, Basel } \\
\text { www.karger.com/crg }\end{array}$ \\
\hline
\end{tabular}

Tomiki et al.: Two Patients with Large Colonic Lipomas for which Endoscopic Unroofing was Ineffective

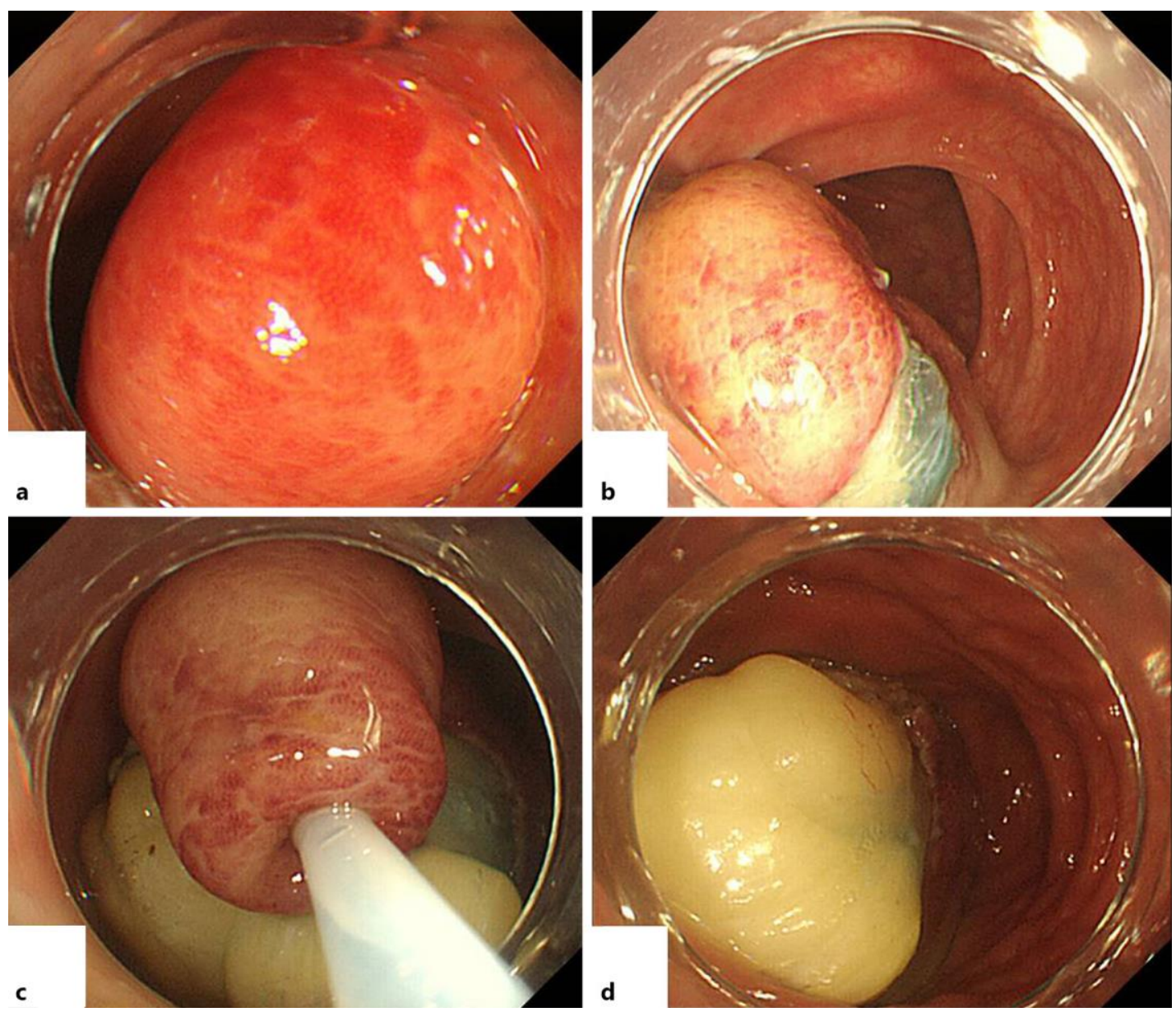

Fig. 2. Colonoscopy findings of lipoma in a 74-year-old man. a A protruding mass with a 50-mm-wide base and thickened, erosive mucosa in the transverse colon. $\mathbf{b}$ Mucosa of the upper third of lipoma after circumferential incision using an electric knife. $\mathbf{c}$ The upper third of lipoma body excised using a snare. $\mathbf{d}$ Adipose material extrudes from the cut surface. 


\section{Case Reports in Gastroenterology}

\begin{tabular}{l|l}
\hline Case Rep Gastroenterol 2016;10:538-544 \\
\hline DOI: 10.1159/000450542 & $\begin{array}{l}\text { C 2016 The Author(s). Published by S. Karger AG, Basel } \\
\text { www.karger.com/crg }\end{array}$ \\
\hline
\end{tabular}

Tomiki et al.: Two Patients with Large Colonic Lipomas for which Endoscopic Unroofing was Ineffective

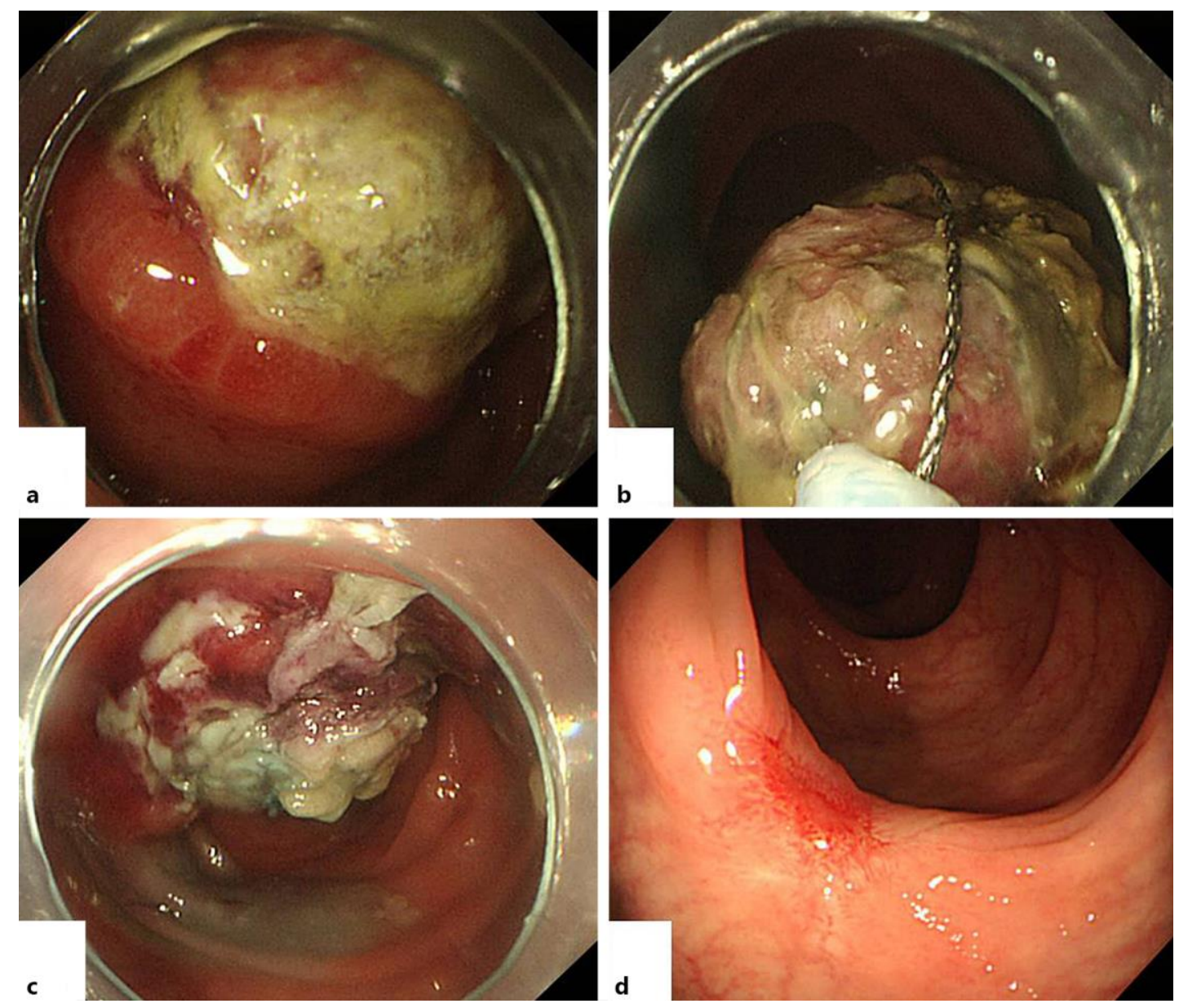

Fig. 3. Colonoscopy findings of lipoma in a 74-year-old man at 1 week after unroofing and 4 weeks after piecemeal EMR. a The unroofed surface was coated with white substance, and the residual lipoma was evident after 1 week. $\mathbf{b}, \mathbf{c}$ The lipoma was removed by piecemeal EMR. $\mathbf{d}$ Four weeks thereafter, the resected region was cicatrized without residual lipoma. 